\title{
Optimal Design of Hybrid Renewable Energy Generation Sources Integrated with Battery Energy Storage System; A Case Study of Nongplathao Park, Chaiyaphum Provincial Administration Organization, Thailand
}

\author{
Montre Chaleekure ${ }^{1}$, Terapong Boonraksa ${ }^{2}$, Nitikorn Junhuathon ${ }^{2}$ and Boonruang Marungsri ${ }^{2, *}$ \\ ${ }^{1}$ Graduate Student in Energy Management Engineering Program, Suranaree University of Technology, Nakhon Ratchasima, \\ Thailand \\ ${ }^{2}$ School of Electrical Engineering, Suranaree University of Technology, Nakhon Ratchasima, Thailand \\ ${ }^{*}$ Corresponding author
}

\begin{abstract}
Hybrid renewable energy began to play an essential role after the fossil energy is gradually reduced. In Thailand, the government is very interested in renewable energy, and there are many potential areas in countries where renewable energy sources such as wind energy and solar energy are available. This paper presents the study results of the optimal design of hybrid renewable energy generation sources integrated with battery storage system in a case study of Nongplathao Park, Chaiyaphum Provincial Administration Organization in Thailand In this study, the On-Grid and the Off-Grid hybrid renewable generation systems were designed, and Homer version 3.11.2 software was used as an analytical tool. The simulation results show that On-Grid renewable energies system can produce electricity supplied to the load and there is also electricity that is sold to the system. The Off-Grid system used renewable energy sources to generate power integrating with the energy storage system for supply electricity to the selection area. Although, an Off-Grid system has expensive installation costs, in the future there is a tendency for lower system equipment costs. This simulation can be used as a case study to promote to other appropriate areas. The simulation results show that On-Grid renewable energies system can produce electricity supplied to the load and there is also electricity that is sold to the system. The Off-Grid system used renewable energy sources to generate power integrating with the energy storage system for supply electricity to the selection area. Although, an Off-Grid system has expensive installation costs, in the future there is a tendency for lower system equipment costs. This simulation can be used as a case study to promote to other appropriate areas.
\end{abstract}

Keywords-hybrid renewable energy; battery storage system; solar energy; wind energy

\section{INTRODUCTION}

Currently, energy is very important to human life. It has also driven the economic and transportation as well. The origin of energy can be divided into two types: non-renewable energy and renewable energy. The primary energy used today is non-renewable energy, such as fossil fuel, uranium, natural gas, etc. In the next few decades, Non-renewable energy is running out. So, we have to focus more on renewable energy. Renewable energy includes solar energy, wind energy, wave energy (water), biomass energy, etc. It is clean energy and preserves the environment [1,2].

The hybrid renewable energy system has played an essential role in the development of electricity. It includes more than two energy sources with off-grid or on-grid to fulfill the load demand. The study of hybrid renewable energy systems has attracted many researchers. They have studied the use of renewable energy systems to meet the load requirements and increase the reliability of the system. The load on each bus was analyzed for the feasibility and the appropriate size of the system model using the Particle Swamp Optimization (PSO) and Genetic Algorithm (GA) methods [3,4]. Develop and design a hybrid renewable energy system consisting of solar and wind energy. Design a stand-alone system with a backup power source. It shows that renewable energy systems are suitable for small community and rural development $[5,6]$. The optimal size of the standalone hybrid wind-solar power generation system with energy storage is studied. Proper allocation of resources according to load requirements is essential, and a thorough analysis of renewable energy resources can significantly reduce system costs $[7,8]$. Renewable energy technology has been studied as a guideline for reducing environmental problems. The energy storage system by Vanadium Redox Battery is used because of its flexibility in power transmission, high efficiency, and long life. HOMER software is used to model wind power systems [9]. The modeling shows the cost of installing wind power systems and energy storage systems.

This paper presents the optimal design of hybrid renewable energy generation sources integrated with the battery energy storage system. The renewable energy sources are PV and wind turbine systems with less capacity coal $52 \mathrm{~kW}$ to supply electricity as shown in Figure I. The study area is Nongplathao 
Park Community, Chaiyaphum Provincial Administration Organization in Thailand. The energy of $1,147.00 \mathrm{kWh} /$ day is the required energy in the area.

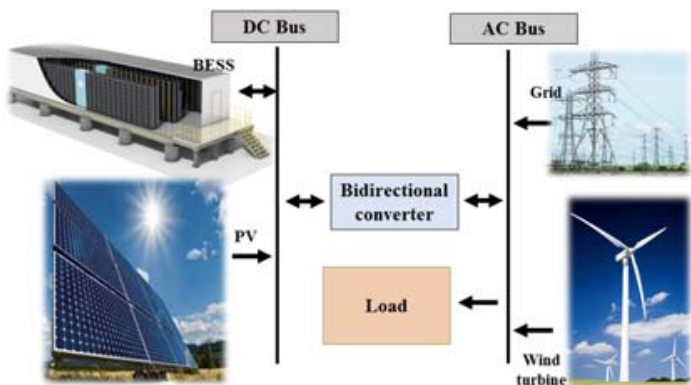

FIGURE I. HYBRID RENEWABLE ENERGY SYSTEM INTEGRATED WITH THE BESS

\section{Methodology}

\section{A. Study Area Location}

The hybrid renewable energy system in this study consists of the wind turbine and solar photovoltaic. Chaiyaphum is a province located in Northeastern of Thailand as shown in Figure II. The Nongplathao Park is a public park in Muang district of Chaiyaphum province.This Public Park is under control of Chaiyaphum Provincial Administration Organization. And this park has a high potential for hybrid renewable energy system installation. This area was selected in this study. Based on the electrical load profile in this study, the average energy consumption per month is $187.18 \mathrm{kWh}$ or equivalent to 162,660.30 Baht/month. For the electricity supply to the offices of Chaiyaphum Province and Nongplathao Park, a power capacity of the renewable energy system is not less than $52 \mathrm{~kW}$.

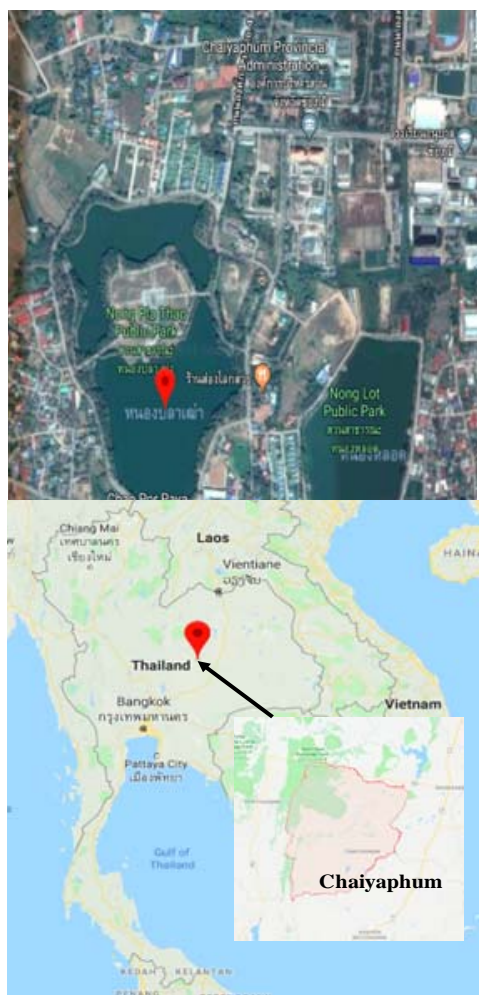

FIGURE II. LOCATION OF THE STUDY AREA

\section{B. Solar Energy Potential}

In Thailand, the solar radiation intensity is in the range of 20-24 MJ/m2-day and the highest average annual sunrise area in the northeastern of Thailand [10]. In the area of Chaiyaphum province, the annual solar radiation was measured and was recorded. The highest average energy in April of each year is $5.458 \mathrm{kWh} /$ day, and the lowest average energy is 4.161 $\mathrm{kWh}$ /day in September. Figure III shows the annual average of global and diffuse solar [11]. Most photovoltaic power generation in Thailand is used in areas with no access to electricity. It produces electricity for small households and connects to the distribution system. However, Large PV generation system is also increasingly installation in Thailand.

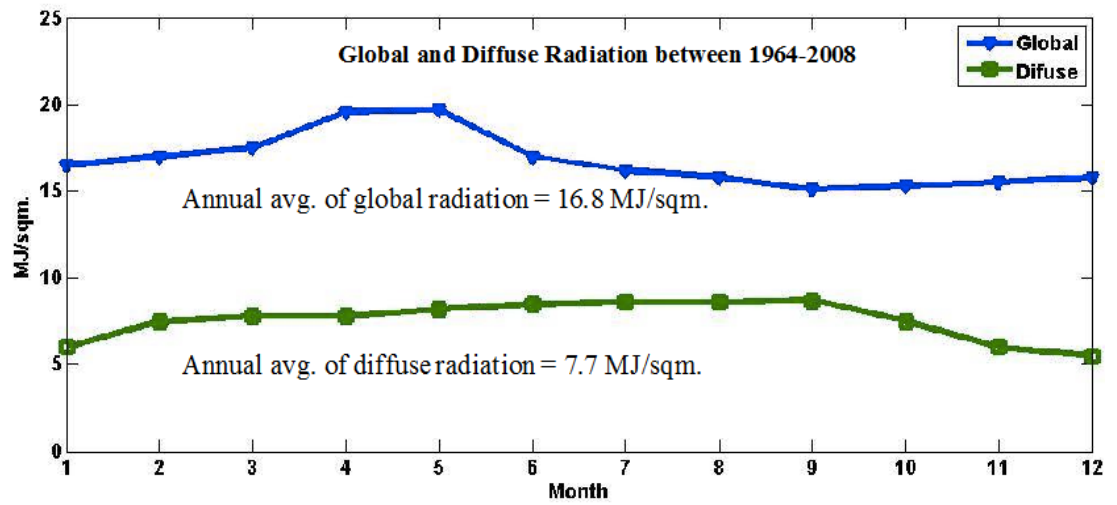

FIGURE III. THE ANNUAL AVERAGE FOR GLOBAL AND DIFFUSE SOLAR 


\section{The Wind Energy Potential}

Wind energy is a natural energy and is clean energy. Wind speed varies with season change in nature. Wind data of study area was measured by the Chaiyaphum measuring station of the department of meteorology, Thailand [12]. For the monthly average, the maximum wind speed is $8.844 \mathrm{~m} / \mathrm{s}$, the minimum wind speed is $5.293 \mathrm{~m} / \mathrm{s}$, and the annual average wind speed is $7.019 \mathrm{~m} / \mathrm{s}$, respectively. For the last decade, low-speed wind turbine for electricity generation has been developed in Thailand. Concerning the wind power potential of the study area, a $10 \mathrm{~kW}$ wind turbine with the minimum operating wind speed to drive power generator at $2.5 \mathrm{~m} / \mathrm{s}$ is suitable for installation. However, due to the fluctuation of wind speed and load demand profile, the energy storage and other reliable sources of renewable energy are required as a hybrid renewable energy generation source.

\section{Simulation Model of Hybrid Renewable Energy System}

Currently, the software for designing and planning of renewable energy generation based microgrids was developed on over the world. Hybrid Optimization Model for Multiple Energy Resources software (HOMER software) is commercial software developed by the National Renewable Energy Laboratory (NREL). It is a powerful tool used for simulating hybrid renewable energy sources. Homer version 3.11.2 was used to simulate the study system. This study, the hybrid renewable energy system model consists of PV and WG integrated with the battery energy storage system (BESS) as shown in Figure IV. As shown in Figure IV, the on the left-hand side is the On-Grid system, and the right-hand side is the Off-Grid system.

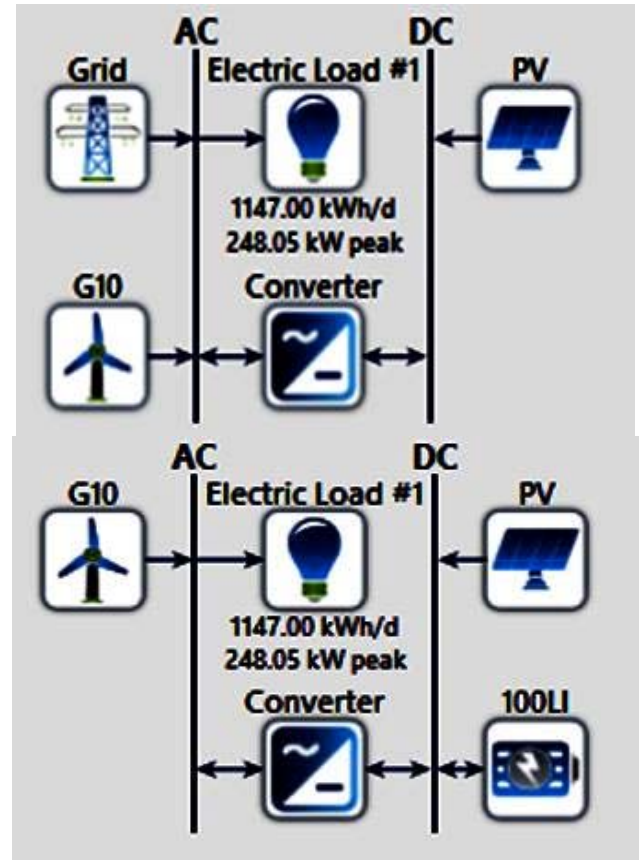

FIGURE IV. SIMULATION MODEL OF THE PV-WIND INTEGRATED WITH BATTERY ENERGY STORAGE SYSTEM (ON-GRID AND OFF-GRID)

\section{SimUlATION RESUlTS}

When Homer Software analyzed the data of the simulated area, the simulation results show that the hybrid renewable energy system can produce $814 \mathrm{~kW}$ of electricity. By considering the low-speed wind turbines with capacity 10 $\mathrm{kW} /$ tower, 17 units were chosen to design for installation in the study area. The solar photovoltaic energy generation, design, and installation in the study area is $644 \mathrm{~kW}$, and the battery energy storage system is a capacity of $1.5 \mathrm{MWh}$. Figure 5 shows the obtained monthly power ratio of renewable energies and the power grid, and Figure 6 shows the obtained monthly power ratio of off-grid renewable energies.

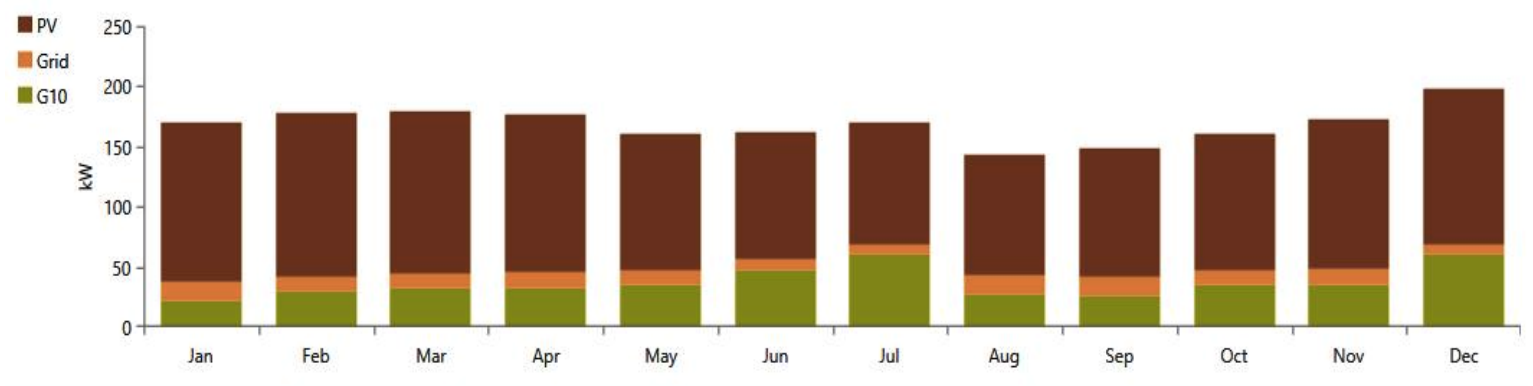

FIGURE V. OBTAINED MONTHLY POWER RATIO OF RENEWABLE ENERGIES AND POWER GRID 


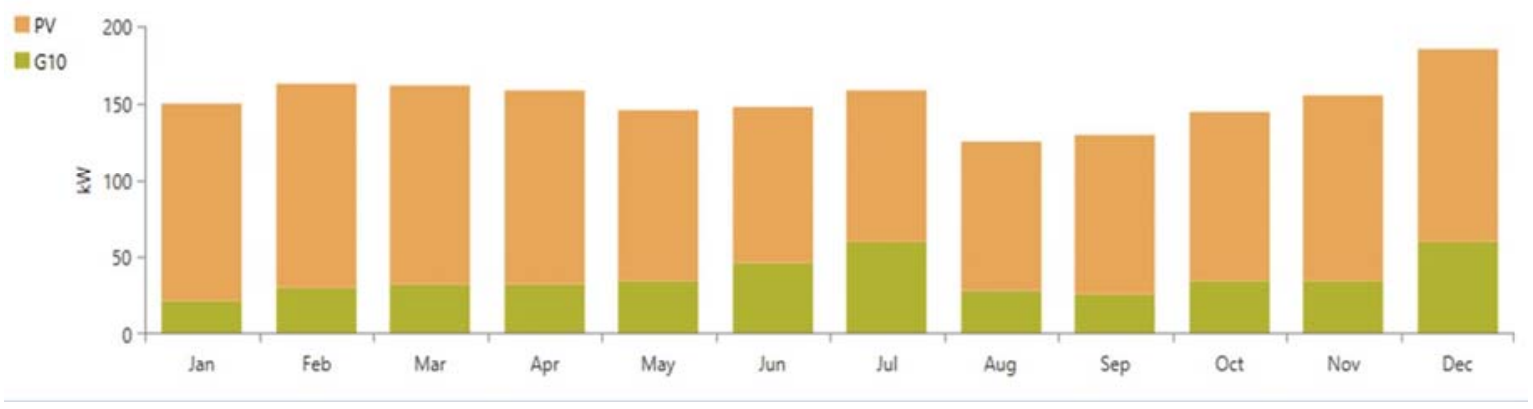

FIGURE VI. OBTAINED MONTHLY POWER RATIO OF OFF-GRID RENEWABLE ENERGIES

The total cost of the On-Grid renewable energy system is 2,906,139 USD which is cheaper than the Off-Grid system. For the Off-Grid system, there is the high cost of PV generation system and the battery energy storage system. If not connected to the power distribution system in the area, the Off-Grid system must have cost a lot. On the other hand, the On-Grid renewable energy system, 110,193 kWh is purchased from the distribution system. The power produced from hybrid renewable energy, 933,575 kWh can be sold to the distribution system. A comparison result is shown in Table I.

TABLE I. INITIAL COST OF THE HYBRID RENEWABLE ENERGY SYSTEM

\begin{tabular}{|c|c|c|}
\hline \multicolumn{3}{|c|}{ Hybrid renewable energy system } \\
\hline & On-grid & Off-grid \\
\hline WT (Generic $10 \mathrm{~kW})$ & $\begin{array}{c}850,000 \\
\text { USD }\end{array}$ & $\begin{array}{c}850,000 \\
\text { USD }\end{array}$ \\
\hline PV (Generic flat plate) & $\begin{array}{c}1,932,000 \\
\text { USD }\end{array}$ & $\begin{array}{c}1,931,398 \\
\text { USD }\end{array}$ \\
\hline $\begin{array}{c}\text { BESS (Generic 100 } \\
\text { kWh Li-Ion) }\end{array}$ & - & $\begin{array}{c}1,050,000 \\
\text { USD }\end{array}$ \\
\hline $\begin{array}{c}\text { System Converter } \\
\text { Total cost of the } \\
\text { system }\end{array}$ & $\begin{array}{c}124,139 \\
\text { USD }\end{array}$ & $\begin{array}{c}84,972 \\
\text { USD }\end{array}$ \\
\hline \multicolumn{2}{|c|}{ USD } & $\begin{array}{c}3,916,370 \\
\text { USD }\end{array}$ \\
\hline
\end{tabular}

\section{CONCLUSION}

The optimal design of hybrid renewable energy generation sources integrating with the energy storage system in a case study of the Nongplathao Park, Chaiyaphum Provincial Administration Organization in Thailand was studied and was simulated in this study by using Homer version 3.11.2. The simulation results show the benefit of the two purposed systems. The On-Grid renewable energies system can produce electricity supplied to the load, and there is also sale electricity to the main grid. The Off-Grid system used renewable energy sources integrating with the energy storage system to generate electricity supply to the selected area. Although, the Off-Grid system shows higher installation costs when compared with the On-Grid system. However, in the future, there is a tendency for lower system equipment costs. This simulation can be used as a case study to promote to other appropriate areas.

\section{ACKNOWLEDGEMENT}

The authors thank the Suranaree University of Technology, Thailand, for providing the laboratory and the financial support.

\section{REFERENCES}

[1] M. Chaleekure, V. Aphichoknithiphuwadol, U. Leeton, B. Marungsri, Feasibility Study of Potential of Hybrid Renewable Energy Generation Sources for Rural Community; A Case of Nongplathao Park Community, Chaiyaphum Provincial Administration Organization, Thailand, The Proceedings of the 5th International Conference on Industrial Application Engineering (2017)

[2] Information on http://www.need.org/files/curriculum/guides/Primary\%20EnergyInfoboo $\mathrm{k}$.pdf

[3] A. Bhave, Hybrid solar-wind domestic power generating system-a case study. Renewable Energy, 17(3) (1999) 355-358.

[4] P. Thounthong, S. Sikkabut, P. Mungporn, P. Sethakul, S. Pierfederici, B. Davis, Differential flatness based-control of fuel cell/photovoltaic/wind turbine/supercapacitor hybrid power plant, 2013 International Conference on Clean Electrical Power (ICCEP), (2013).

[5] P. Nema, R. Nema, S. Rangnekar, A current and future state of the art development of hybrid energy system using wind and PV-solar: A review. Renewable and Sustainable Energy Reviews, 13(8) (1009) 2096-2103.

[6] K. Basaran, N.S. Cetin, S. Borekci, Energy management for on-grid and off-grid wind/PV and battery hybrid systems, IET Renewable Power Generation, 11(5) (2017) 642-649.

[7] W. Zhou, C. Lou, Z. Li, L. Lu, H. Yang, Current status of research on optimum sizing of stand-alone hybrid solar-wind power generation systems. Applied Energy, 87(2) (2010) 380-389.

[8] A. Kaabeche, M. Belhamel, R. Ibtiouen, Sizing optimization of grid-independent hybrid photovoltaic/wind power generation system, Energy, 36(2) (2011) 1214-1222.

[9] A. Stiel, M. Skyllas-Kazacos, Feasibility Study of Energy Storage Systems in Wind/ Diesel Applications Using the HOMER Model. Applied Sciences, 2(4) (1012) 726-737.

[10] Renewable energy outlook, Minister of Energy Thailand 197-229. (2017)

[11] Guide for development and investment on energy production, Volume 2, Solar Energy, Department of Alternative Energy Development and Efficiency, Ministry of Energy (2010)

[12] Energy situation report of Chaiyaphum Province (2013) 